\title{
أهمية تعليم اللغة العربيّة في فهم القران العظيم
}

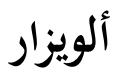

جامعة السلطان الشريف قاسم الإسلامية الحكومية رياو، اندونيسيا

ملخّص

اتفق العلماء على أن تعليم اللغة العربية هو جزء من الدين وواجب ديني. إن العلم باللغة

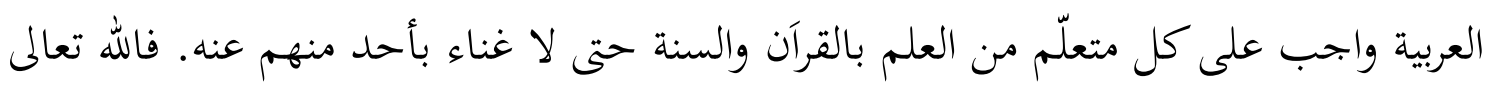

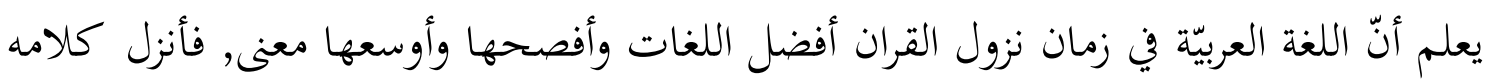

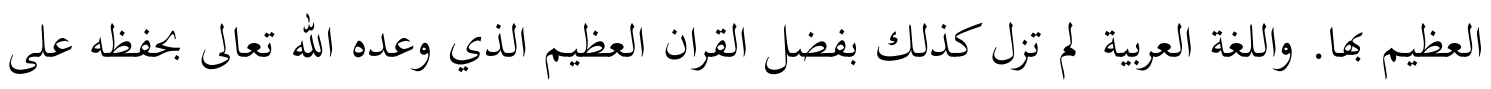

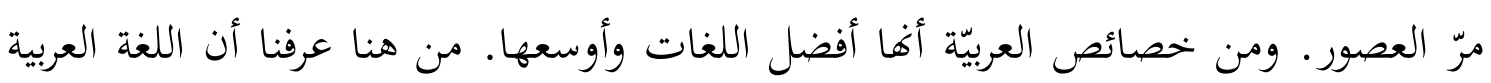

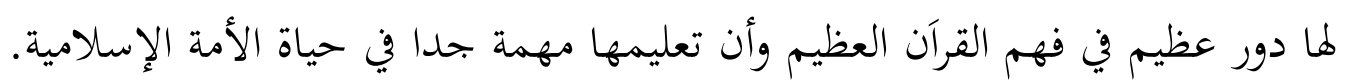

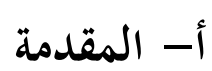

إن من مميزات اللغة العربية في نظر الدين الإسلامي أها لغة القرأن الكريم ولغة السنة

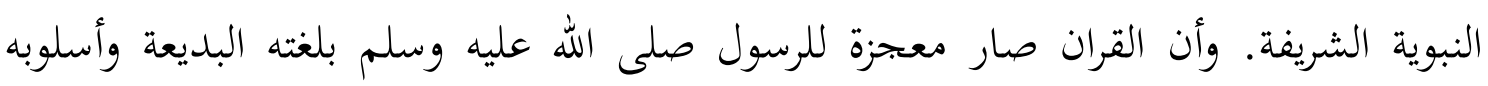

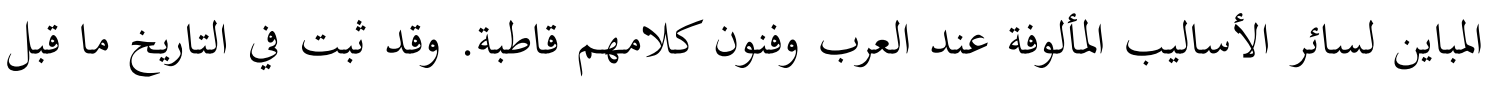

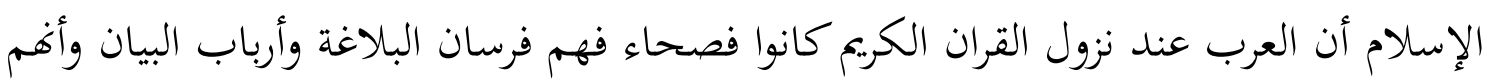

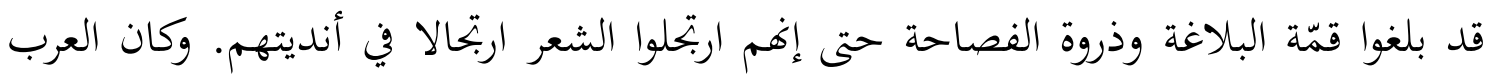

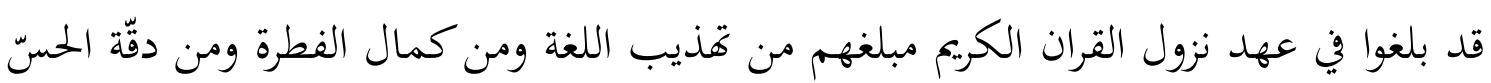

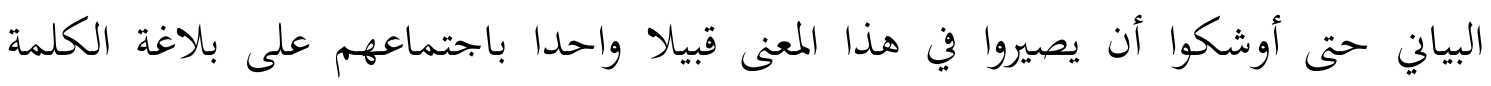
وفصاحة المنطق.'

وقد كان من عادات العرب أن يتحدى بعضهم بعضا في المساجلة والمقارضة بالقصيدة

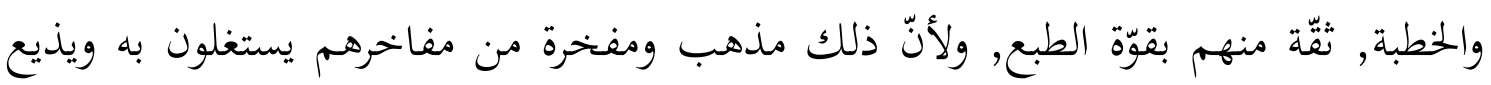

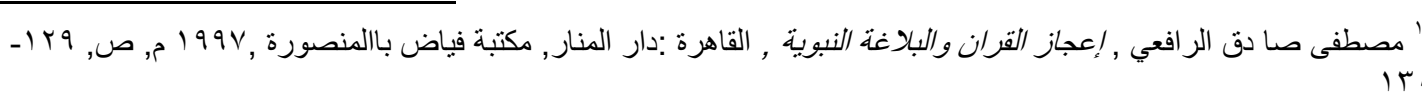

rol

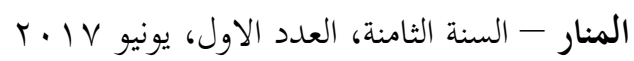


لهم حسن الذكر وعلوّ الكلمة وهم بحبولون عليهم فطرة. وكانو يعلّقون أشعارهم على الكعبة

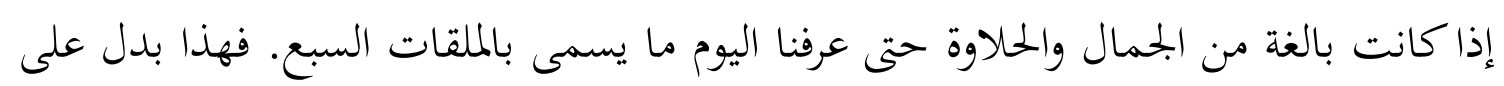

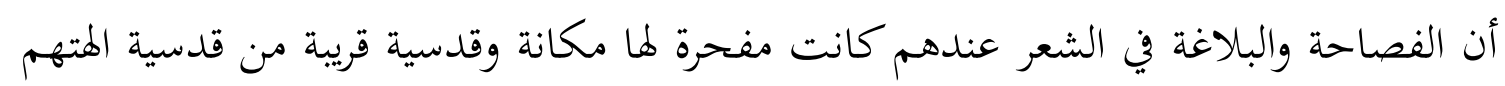
من الأصنام حيث وضعوها حول الكعبة كما وضعوا تلك الأصنام المعبودة.

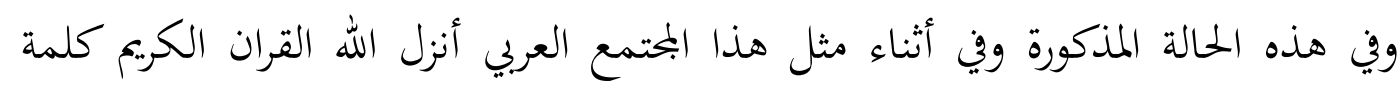

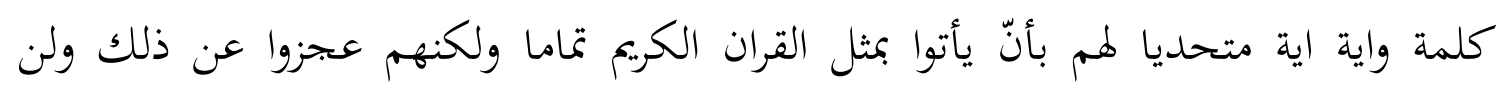

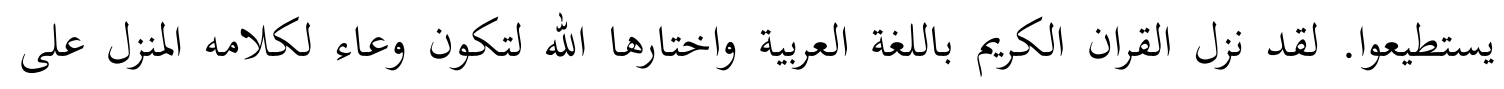

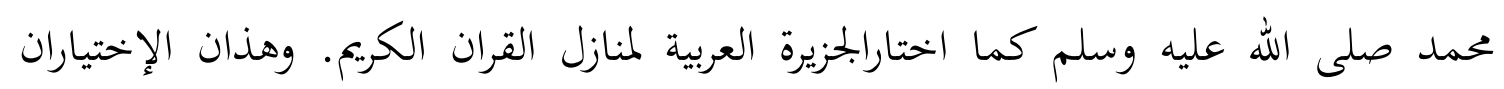

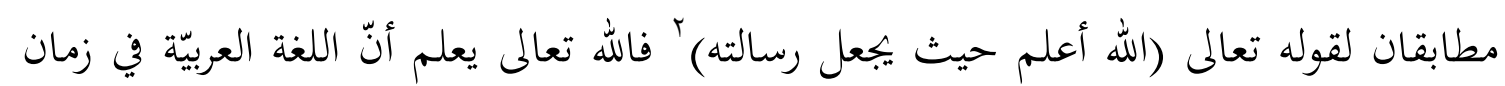

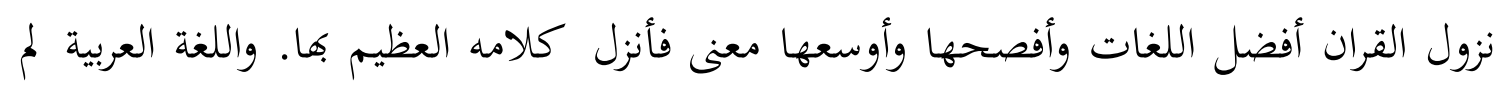

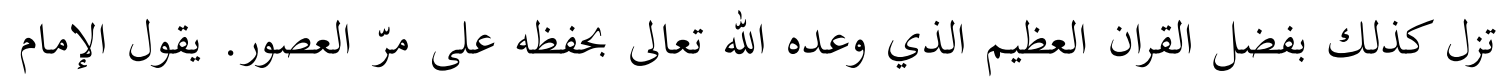

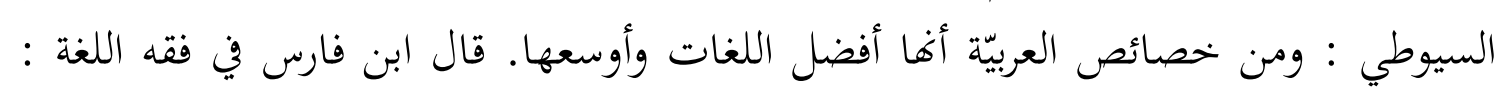

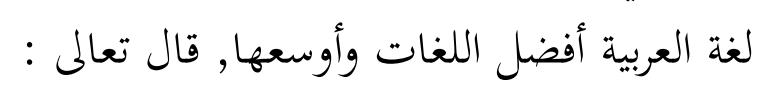

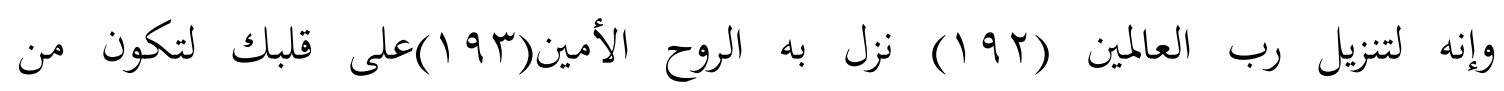

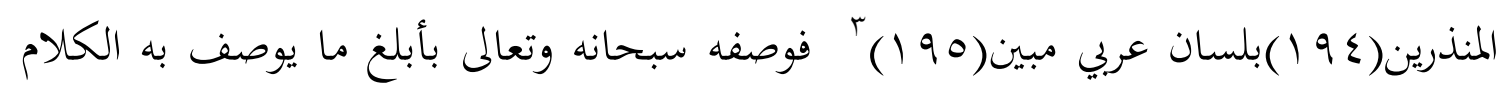
وهو البيان.

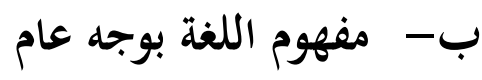

لم يتفق علماء اللغة على تعريف واحد للغة, ويعود عدم اتفاقهم إلى ارتباط علم اللغة

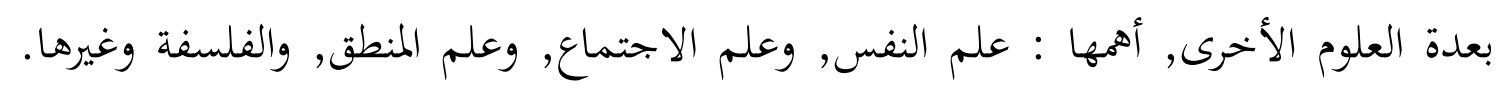

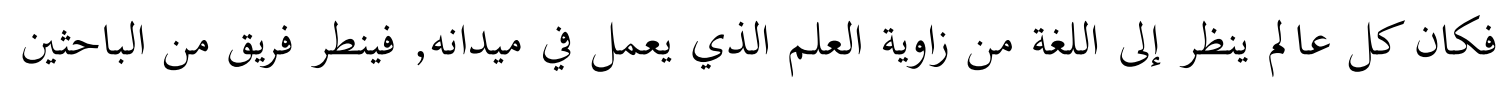

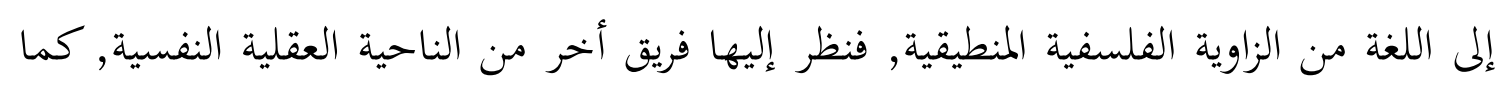

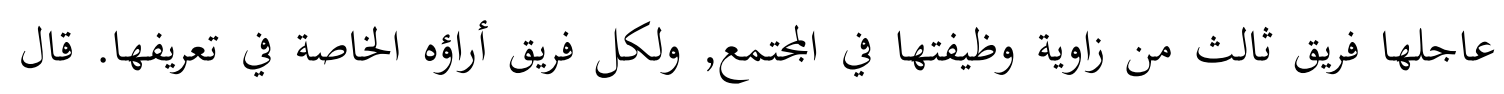

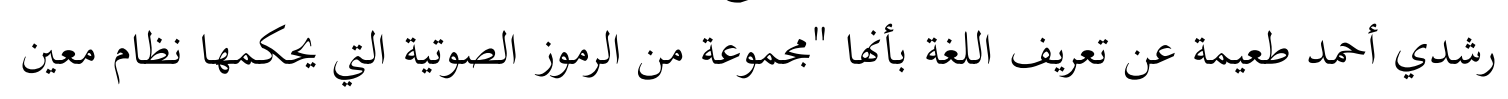

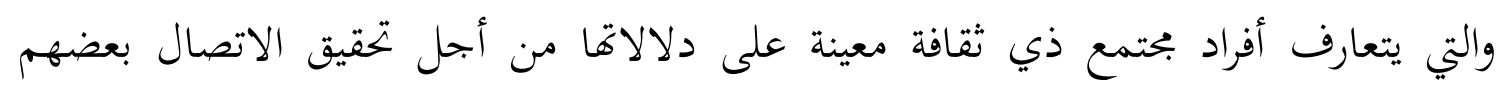

\footnotetext{
$\underline{-10}$ 
ببعض." ورأينا أيضا عن تعريف اللغة كما قال أبو الفتح عثمان ابن جني , بأن اللغة هي أصوات يعبرها كل قوم عن أغراضهم.

اللغة هي وعاء الفكر, أو هي فكر ناطق لغة صافه صامتة ويعدها البعض معجزة الفكر

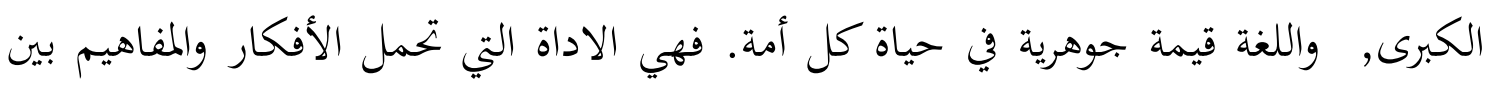

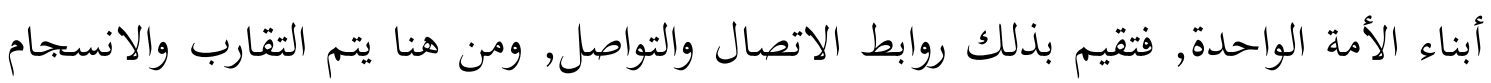

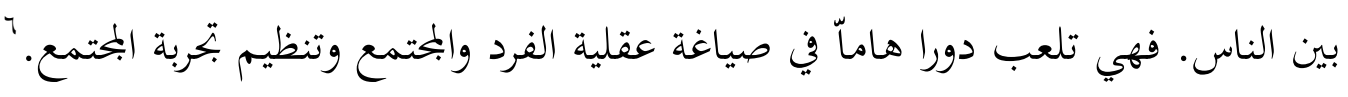

\section{ت- مميزات وحصائص اللغة العربية}

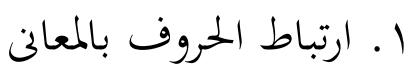

إن ارتباطا بين الحروف ودلالة الكلمات في العربية فقد ذكر علماء المباء العرب من الأمثلة

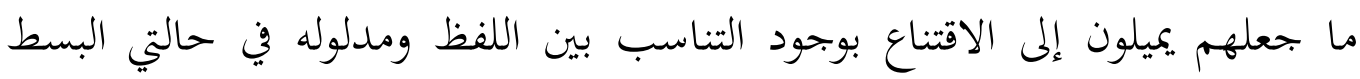

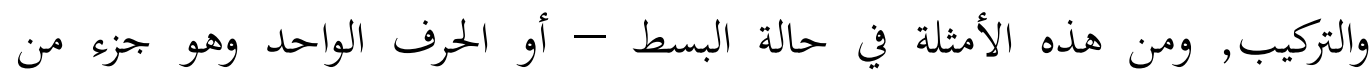

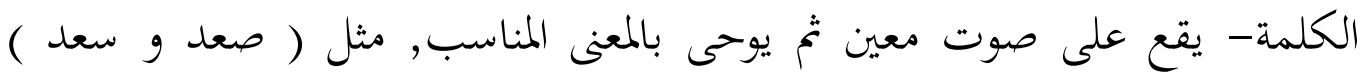

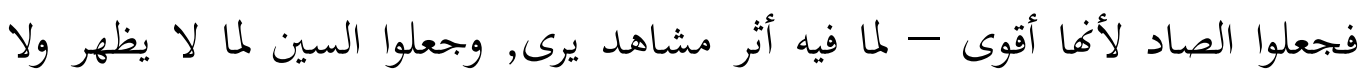

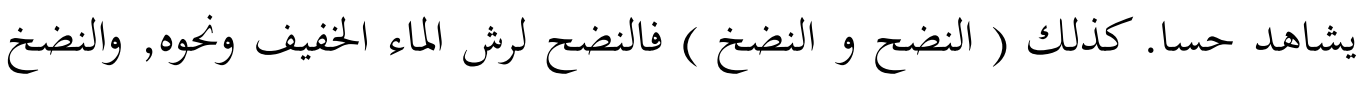

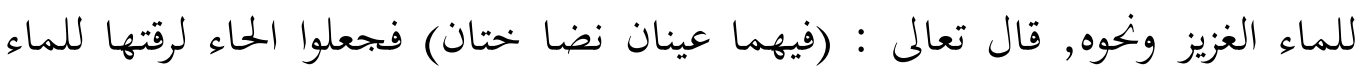

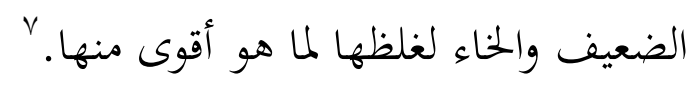
r إيجاد المفردات المترادفة

الترادف هو إطلاق عدة كلمات على مدلول واحد. فا لألفاظ المترادفة هي ألفاظ الحد

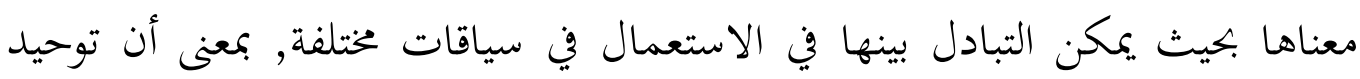
كلمتان تحملان معنى واحدا, وقابله التبادل فيما بينها في أي سياق.

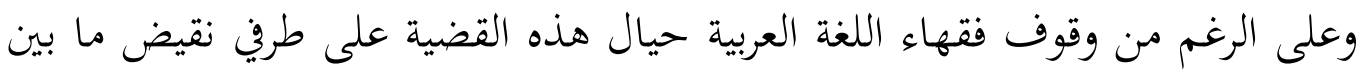

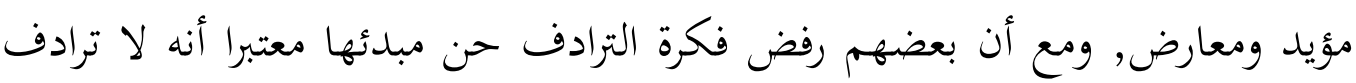
على الحقيقة, وأن لكل لفظة معنى ليس في الأخر كما في أسماء الأسد, أو أسماء السيف, نقول على الرغم من ذلك, فإنا لا نعدم بعض فقهاء اللغر اللغة الذين انتصروا

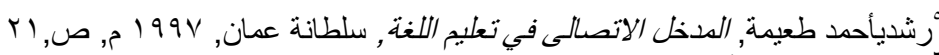

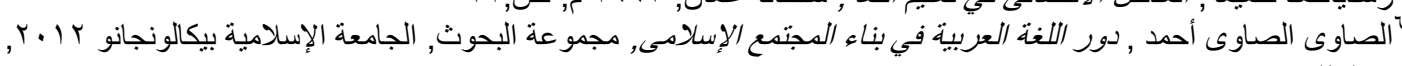

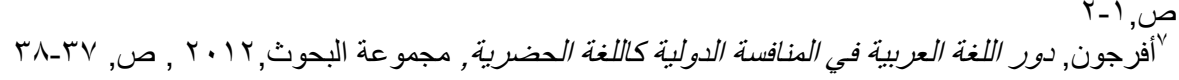


لفكرة الترادف كابن جنى. أن الترادف ظاهرة حقيقة في اللغة العربية, وكانت أسبابها كالآتية : 1. إن احتكاك لغة قريش باللهجات العربية الأخرى نقل إلينا مفردات هذه اللهجات.

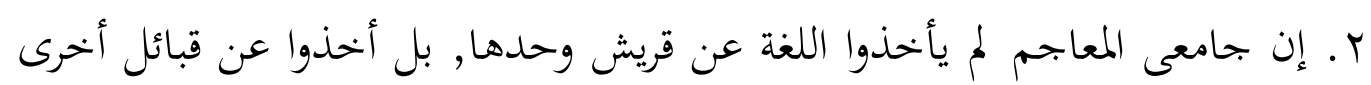
كثيرة. r. إن جامعى المعاجم - لشدة حرصهم على تسجيل كل شيء-سجلوا كل المفردات. ومعنى هذا أن الشيء الواحد : كالسيف, أو الجمل, أو الأسد, مثلا, له اسم في

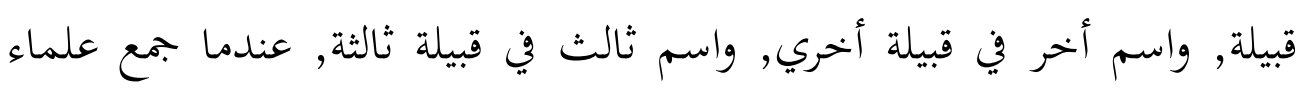

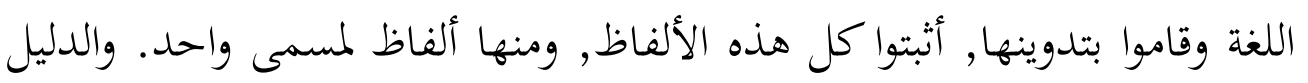

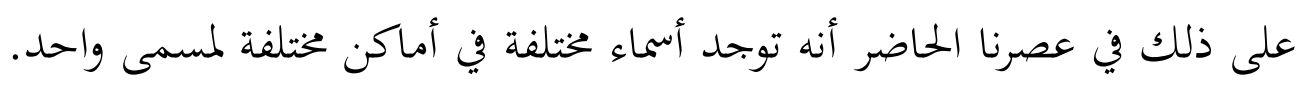

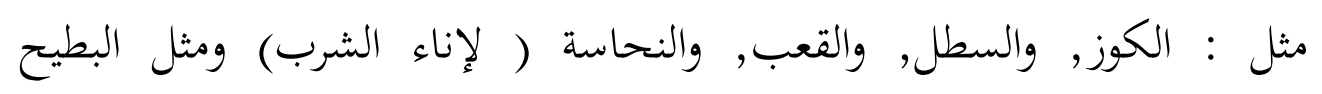

$$
\text { r. الاشتقاق في اللغة والحبح (للبطيح) وهكذا في مسميات أخرى. }
$$

الاشتقاق هو أخذ كلمة من كلمة, أو توليد لبعض الألفاظ من بعض لوجود علاقة

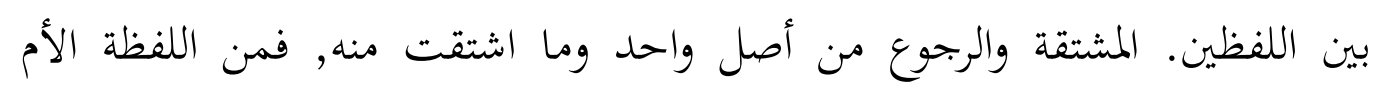

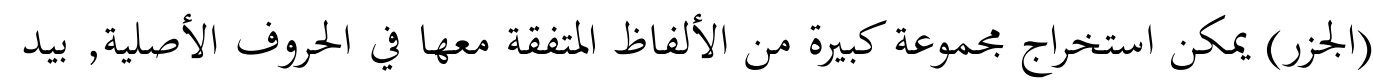

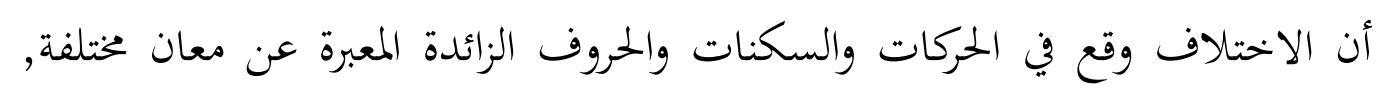

$$
\text { ع. مثلا في : قرأ- بقرأ- قراءة- اقرأ- مقروء. }
$$

تتميز اللغة العربية بأها تمتلك أوسع مخرج صوتى عرفته اللغة, فهي تحتوى على نهو

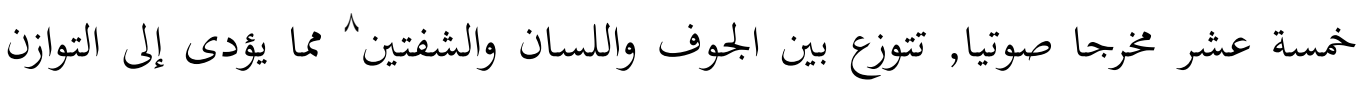

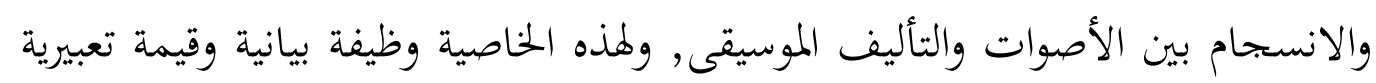

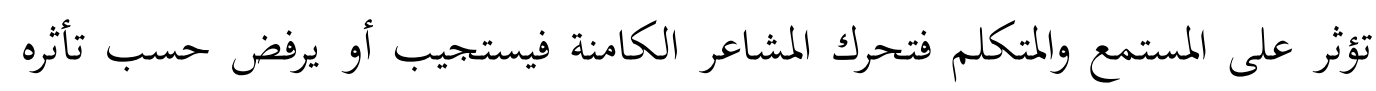

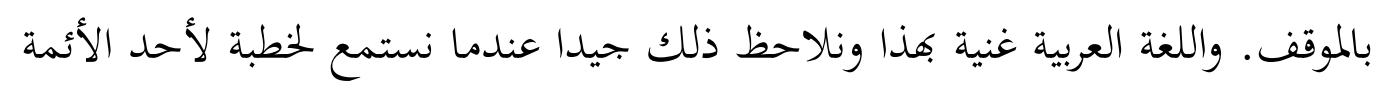
أو قصيدة لأحد الشعراء وهو يتناغم بها. فحسب الموقف يستطيع الإنسان تغييرموقفه 
سواء بالتعاطف سعادة أو حزنا مما يؤدي في النهاية إلى تحقيق الهدف الذي ينشده

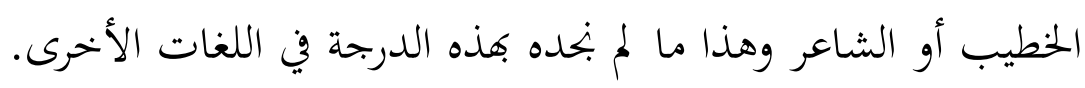

$$
\text { ه. من ناحية الأساليب }
$$

تتميز اللغة العربية بقدرها على التصرف في الأساليب والعبارات وعلى التنوع في التراكيب, وذلك بحسب المقام الذي يتطلب نوعا من الأساليب دون غيره من تقديم

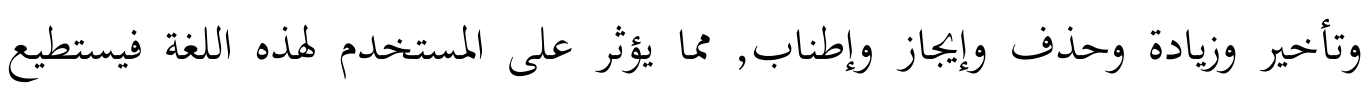

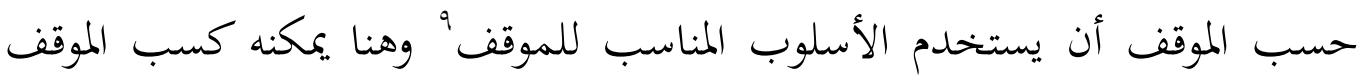

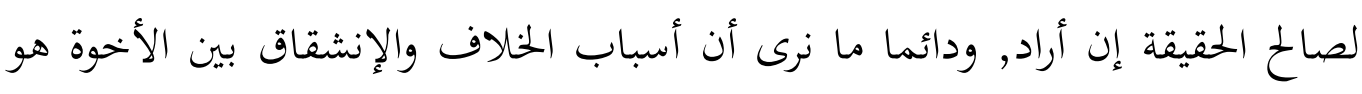

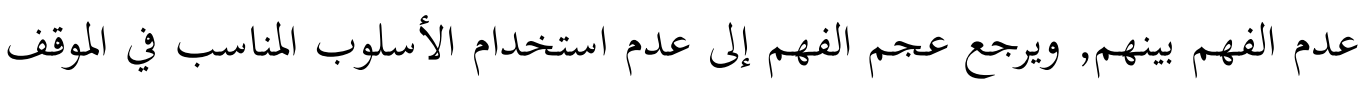

ث- اللغة العربية وقضية حفظ القرآن

ذكر الزركشى أن الصحابة المهاجرين والأنصار اتفقت كلمتهم على قراءة القرآن

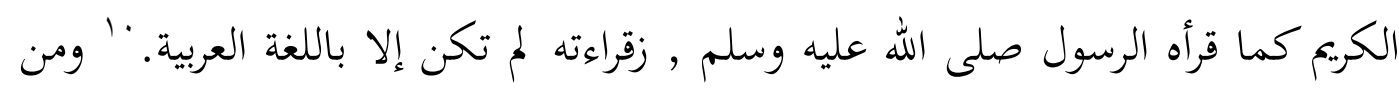

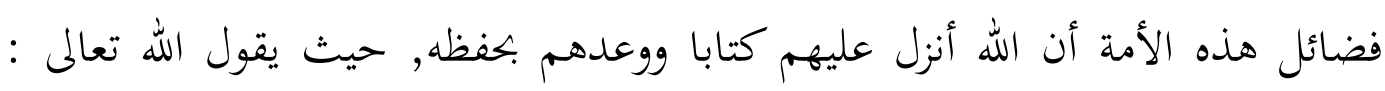

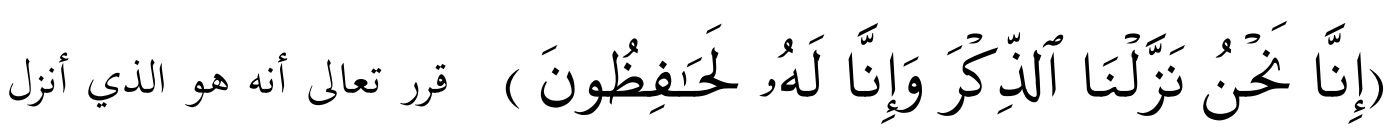
عليه القرآن وهو الحافظ له من التغيير والتبديل. وذلك بخلاف الأمم السابقين فقد كانوا

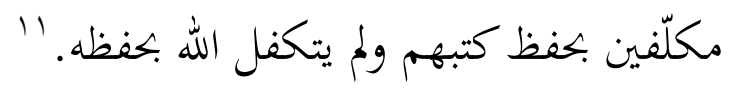

ومن مظاهر حفظ الله تعالى للقرآن أن يعدّ الله تعالى القرّاء الحافظين منذ أن أن نزل

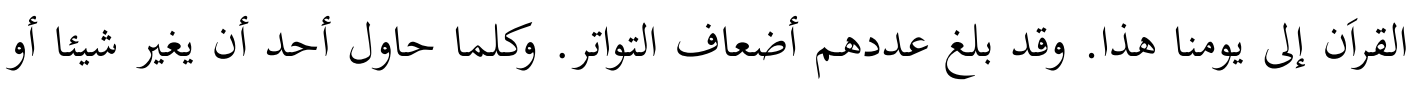

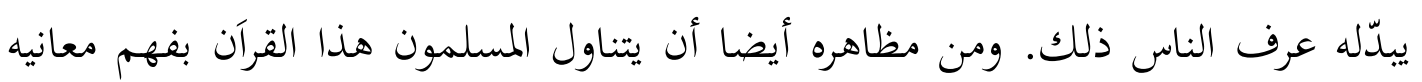

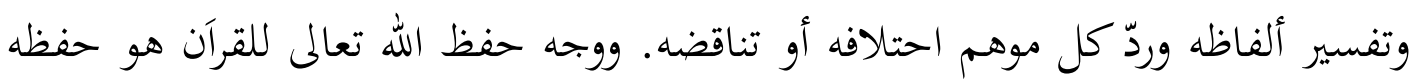

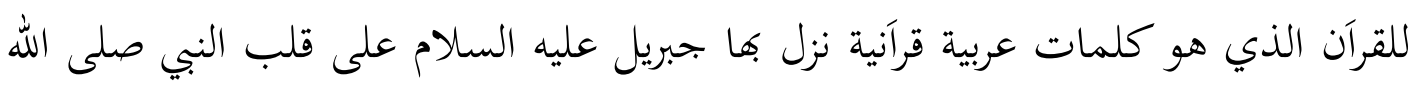
عليه وسلم وهو القرآن الكريم الذي يستخدم اللغة العربية.

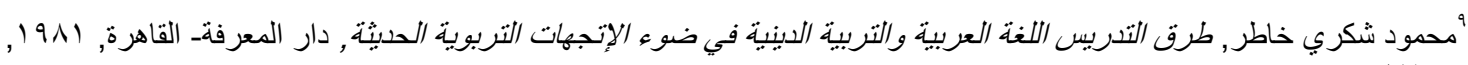

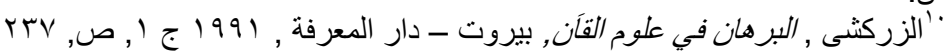

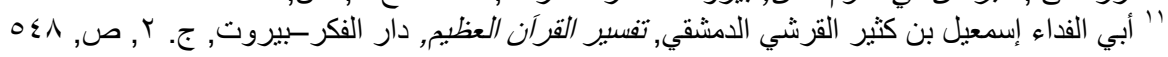


وبالجملة, إن القرآن الكريم محفوظ وهذا الحفظ يكون بلغته العربية حيث يسّر الله

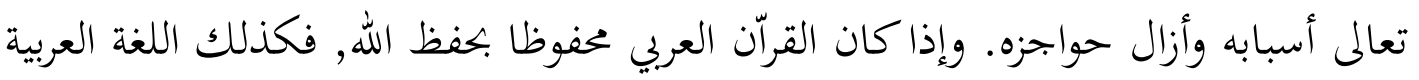

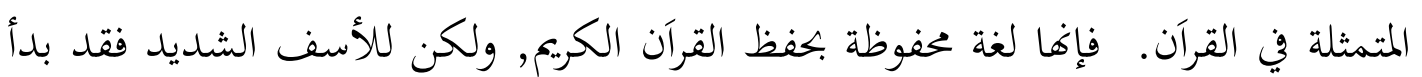

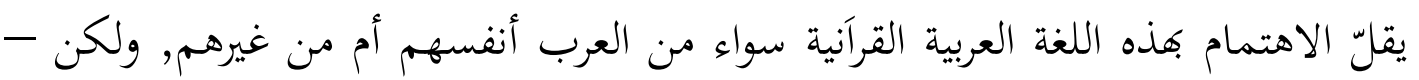

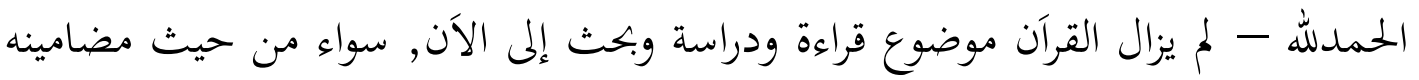

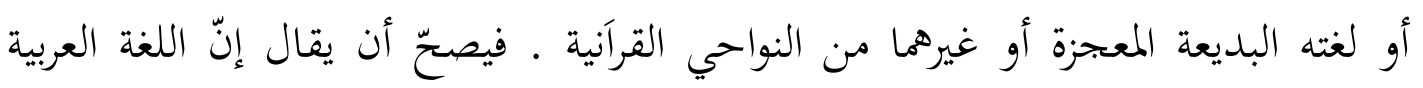

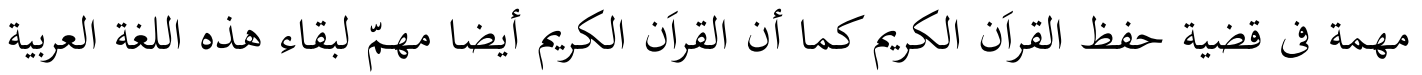

$$
\text { ج-اللغة العربية وقضية إعجاز الأمم الإسلامية العربية وغير العربية. }
$$

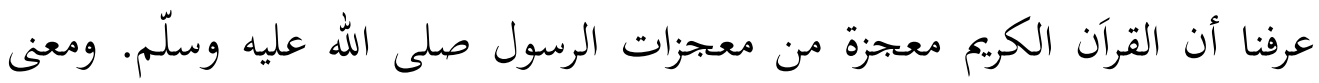

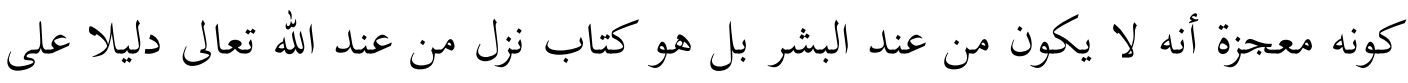
صدق نبوة محمد صلّى الله عليه وسلم.

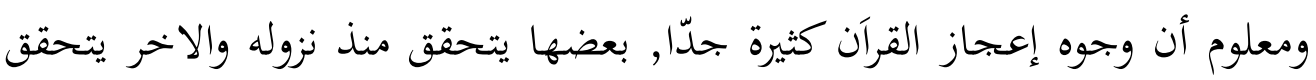

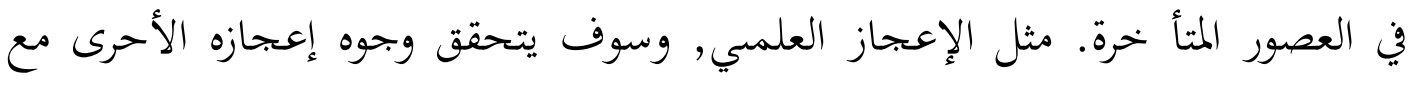

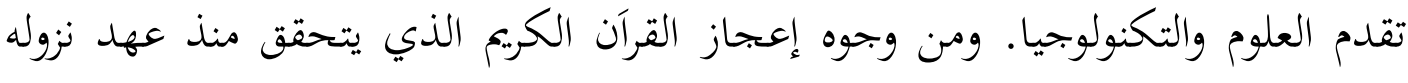

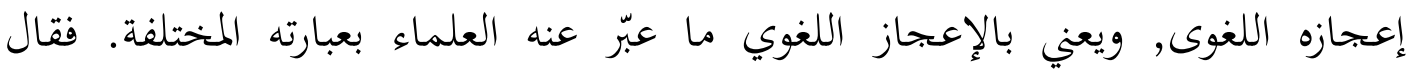

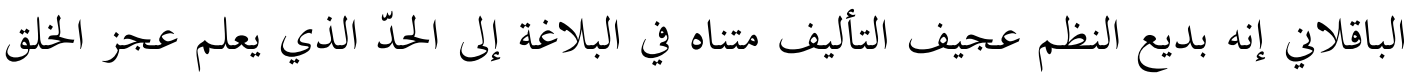

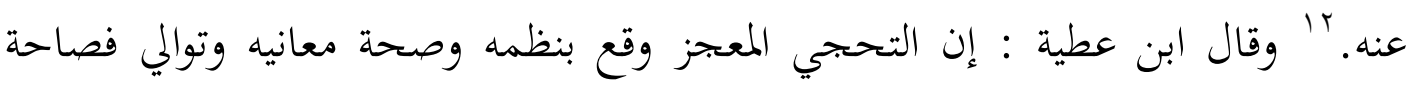

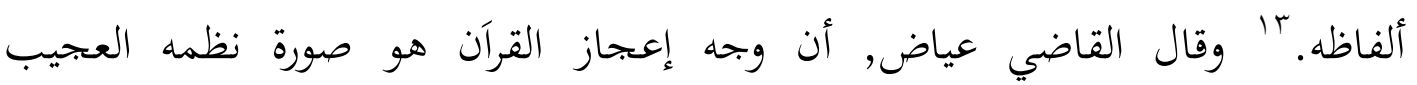

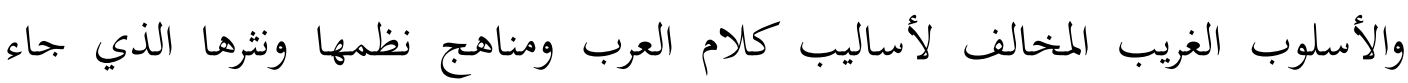

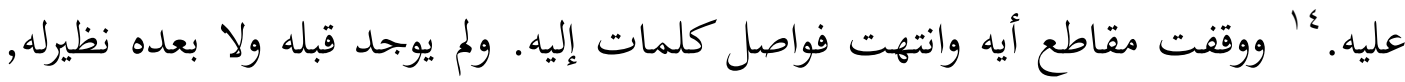

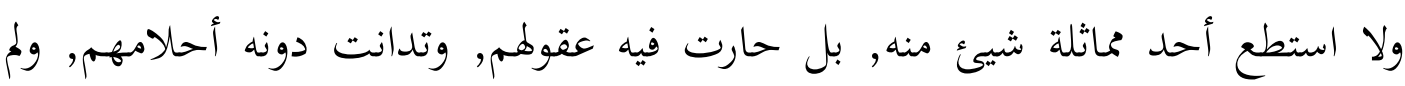

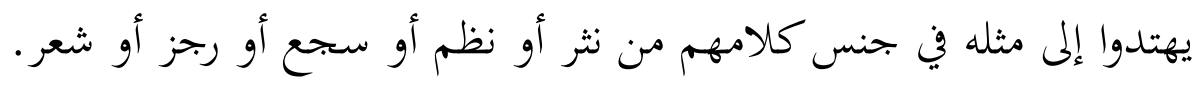

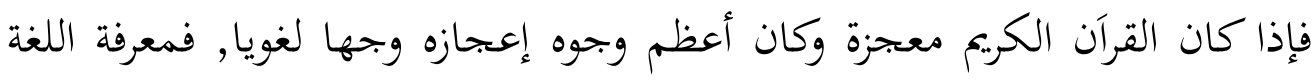

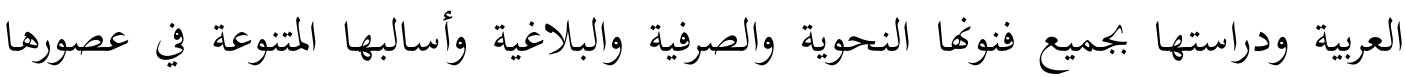

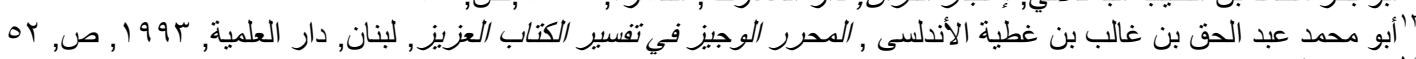

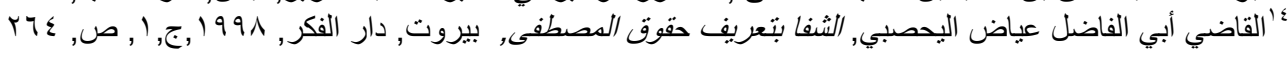


المختلفة. بداية من عصر ما قبل الإسلام ثم عصر النبوة والرسالة ثم عهد الأموية والعباسية

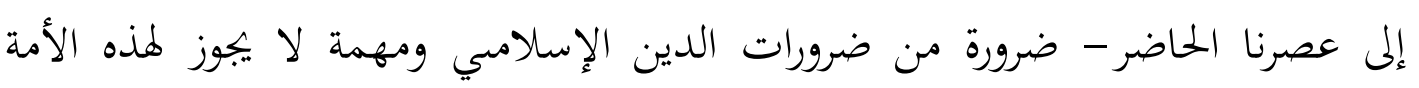

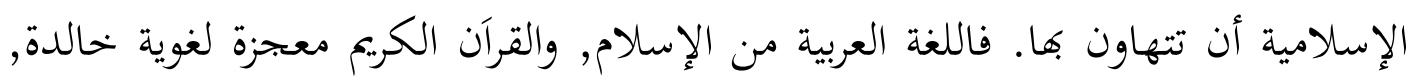

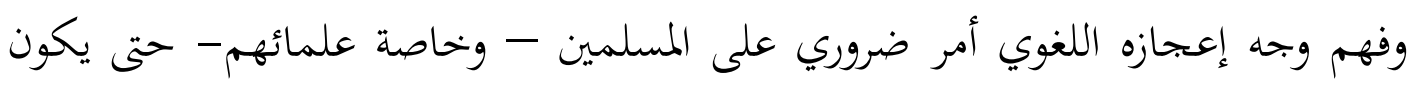

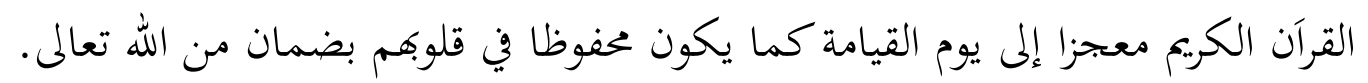

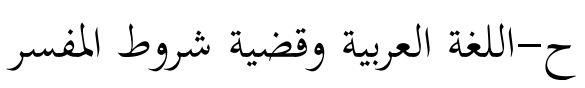
إن القرآن كلام معجز فالق سائر الكلام من حيث المعبث اللفظ والمعنى فليس جميع الناس

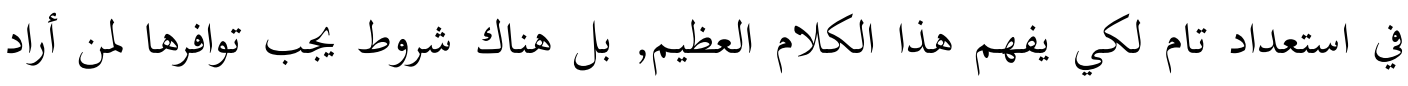

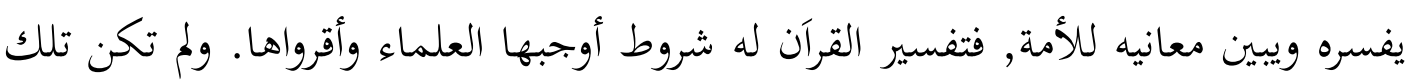

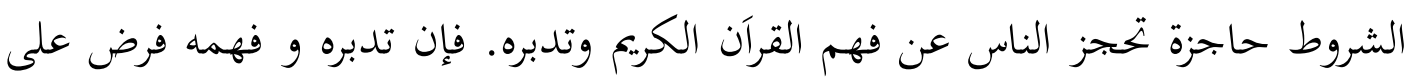

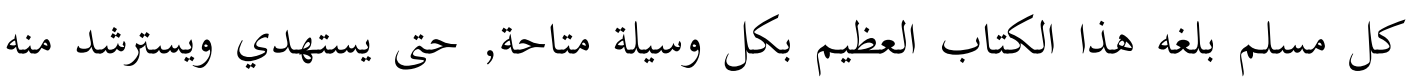

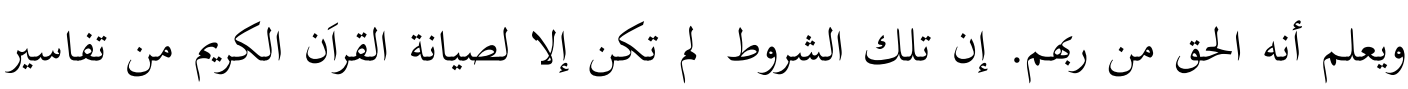

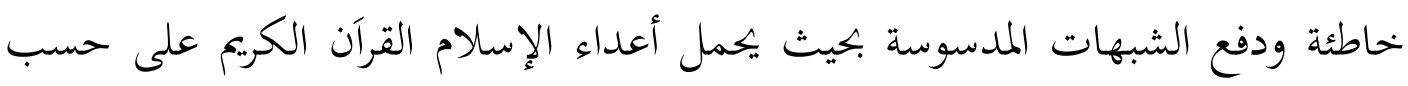

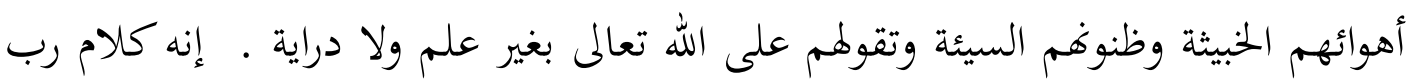

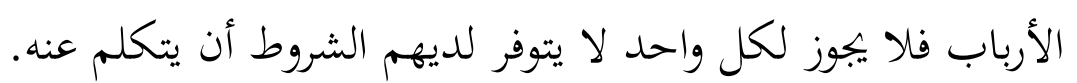

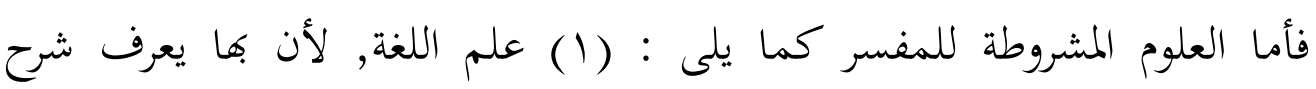

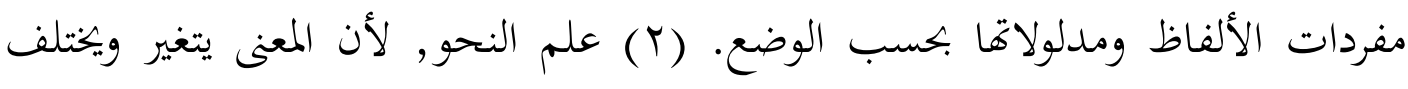

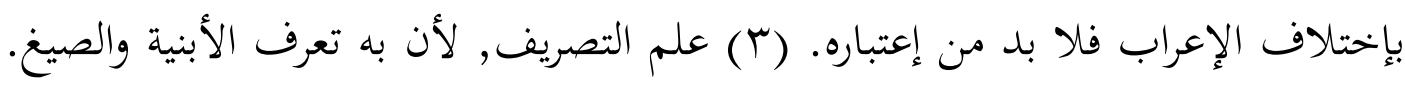

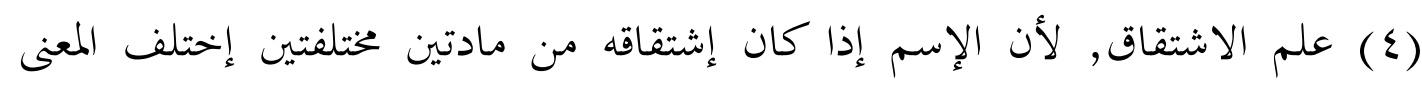
بإختلافها. (0) علم المعاني, لأنه يعرف بالأول خوهص تراكيب الكالام من جهة إفادة إنها

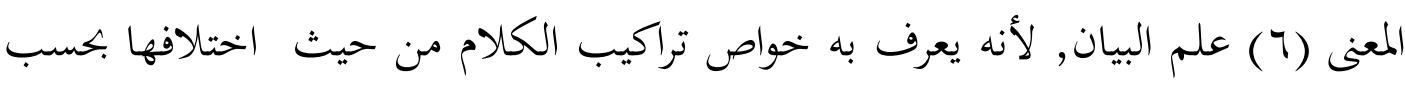

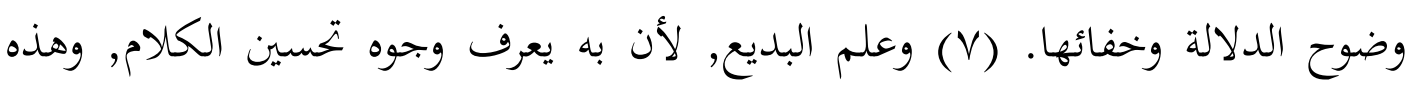

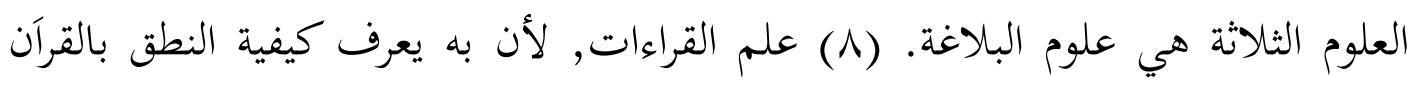

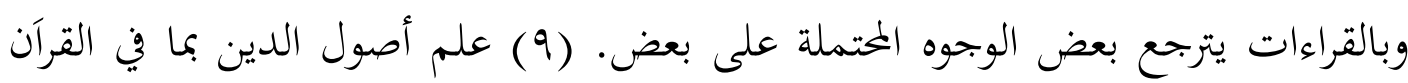

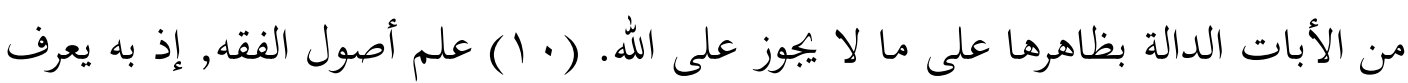

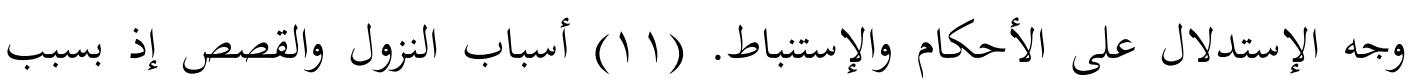

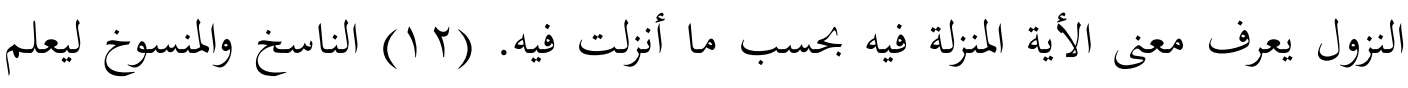




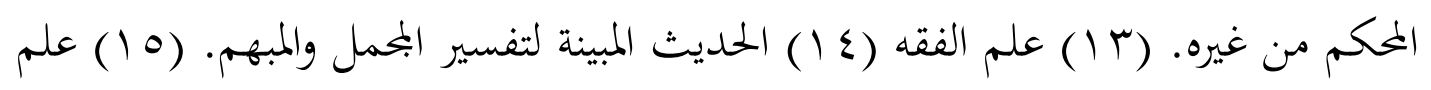

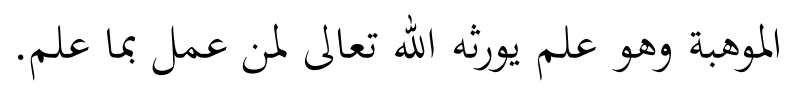

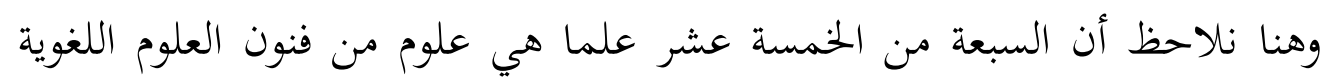

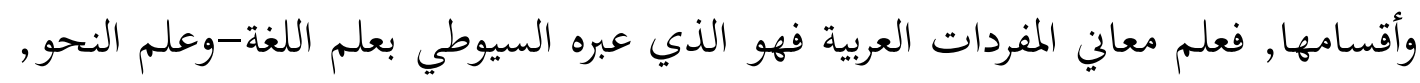

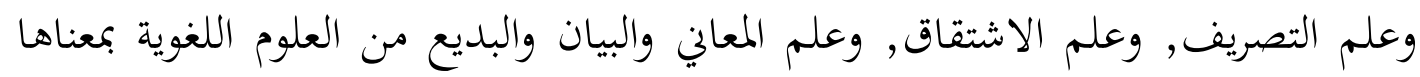

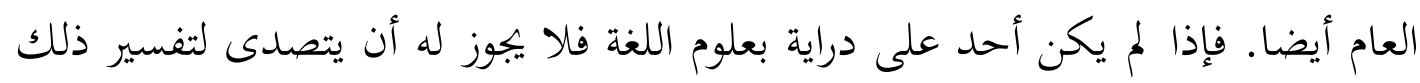

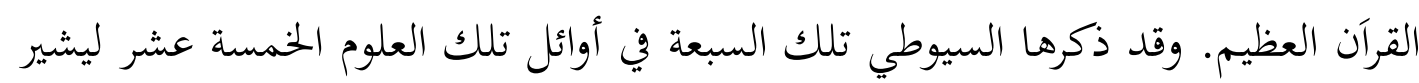
إلى أها من أهم تلك العلوم المشروطة وأولها وجوبا قبل العلوم الأخرى المثاك المذكورة هناك.

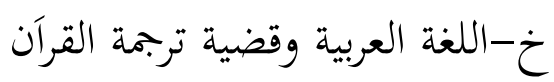

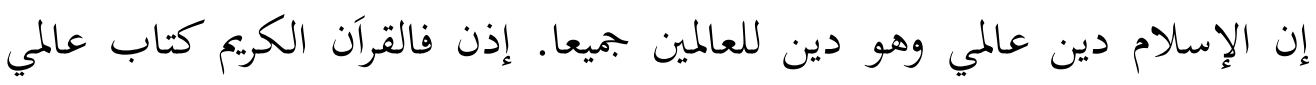

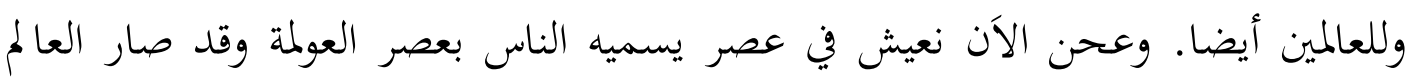

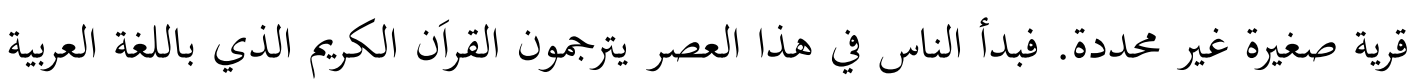

$$
\text { إلى لغات أخرى غير اللغة العربية. }
$$

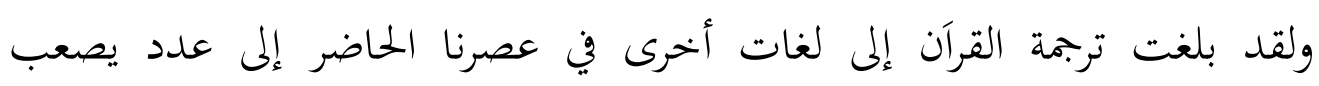

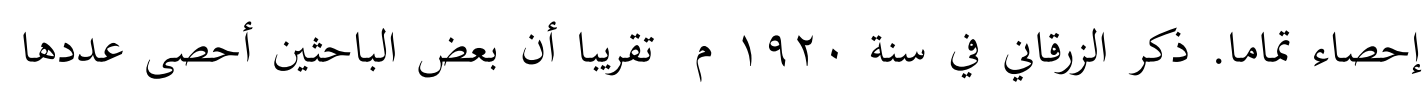

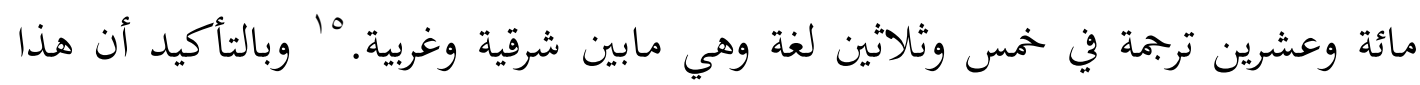

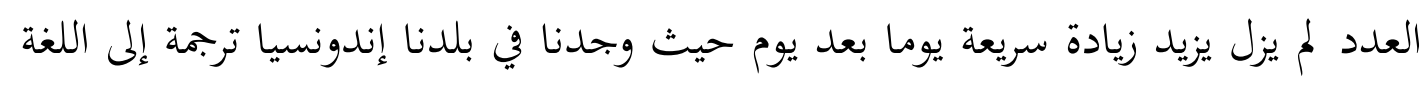

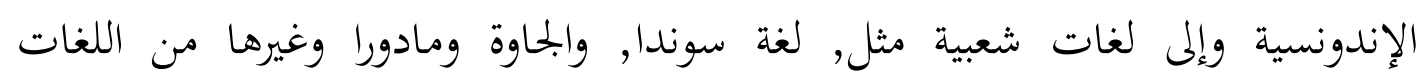

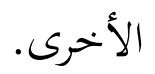

اختلف العلماء قديما وحديثا في حكم ترجمة القرآن بين المانعين والمجوزين. وقال محمد

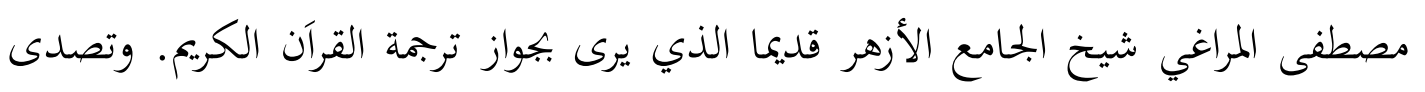

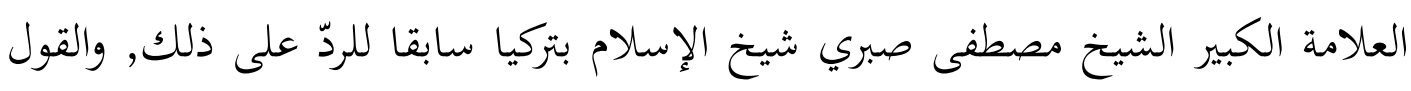

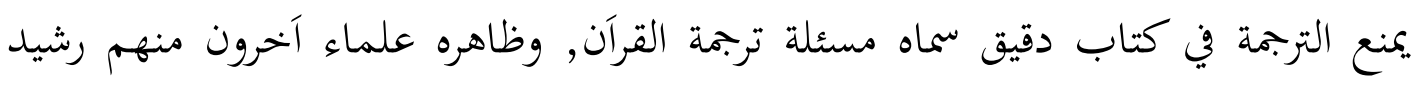

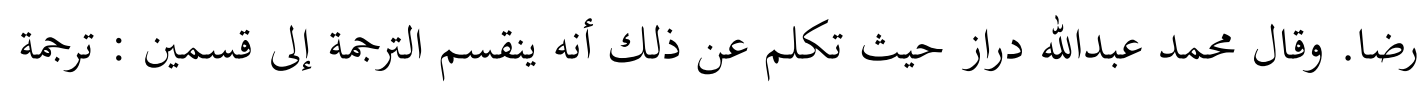

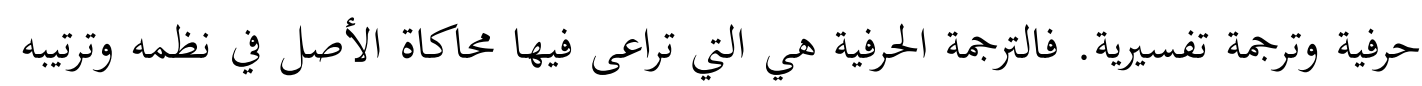

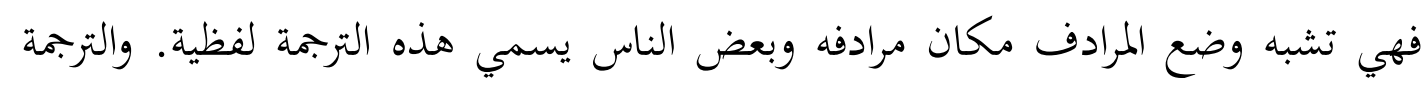


التفسيرية هي التي لا تراعى فيها تلك المحاكاة أي محاكاة الأصل في نظمه وترتيبه بل المهم فيها حسن تصوير المعاني والأغراض كاملة ولهذا تسمى أيضا بالترجمة المعنوية. 17

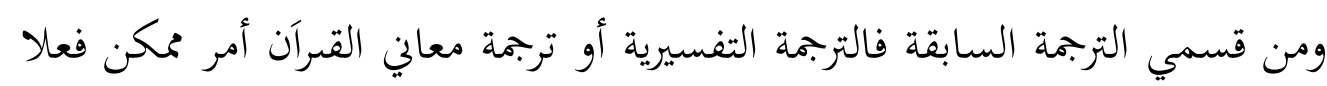

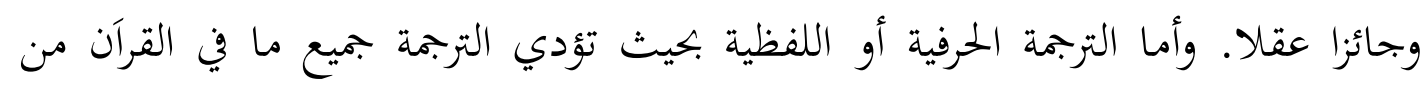

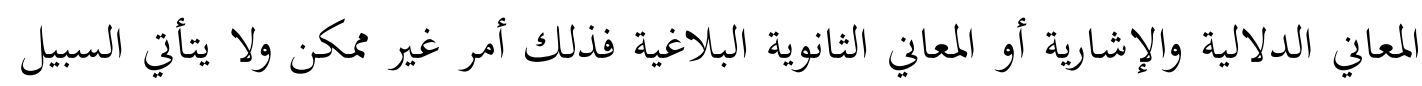
إلى ذلك.

د. الخاتمة

اللغة هي وعاء الفكر, أو هي فكر ناطق لغة صامتة ويعدها البعض معجزة الفكر

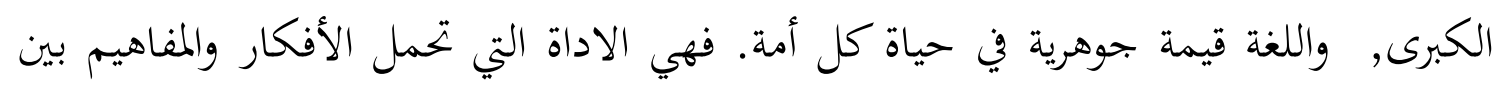

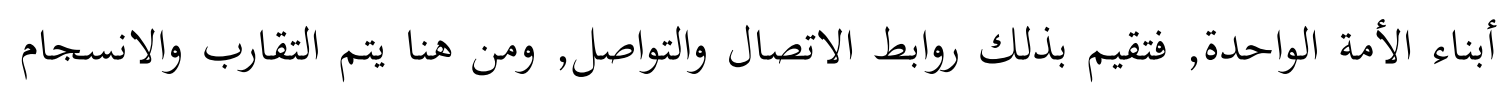

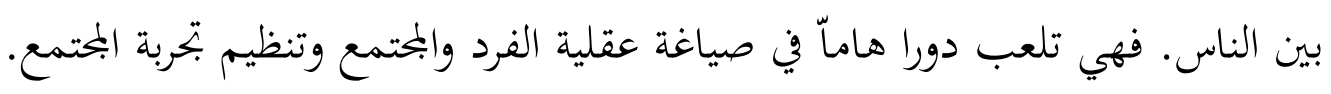

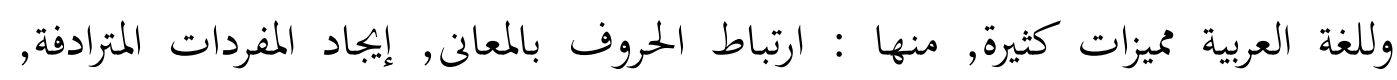

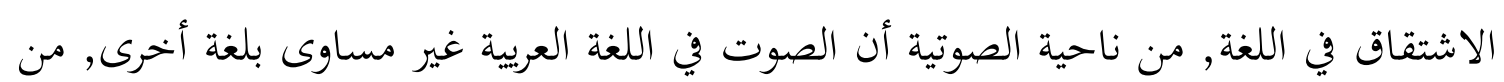

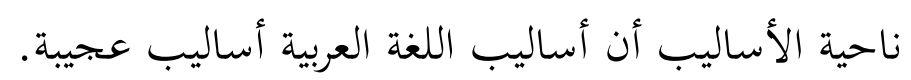

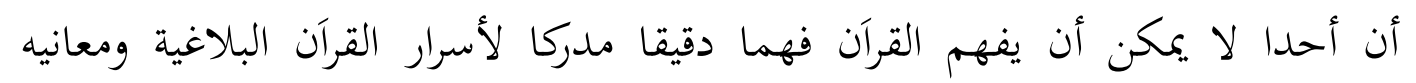

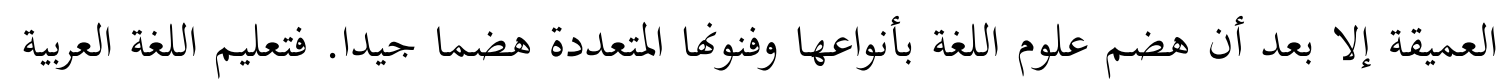
له دور عظيم في فهم القرآن الكريم.

\section{المراجع}

أبي الفداء إسمعيل بن كثير القرشي الدمشقي، تغسير القرآن العظيم، دار الفكر-بيروت

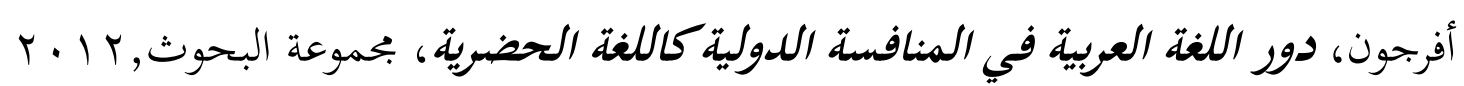

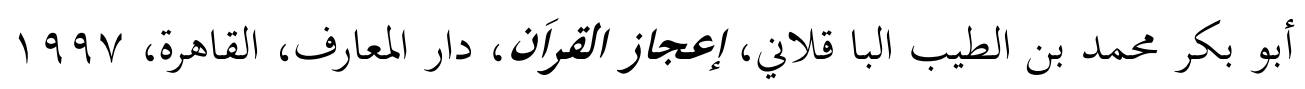

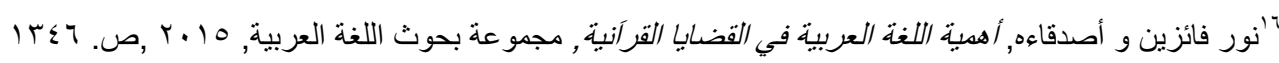


أبو محمد عبد الحق بن غالب بن غطية الأندلسى، المحرر الوجيز في تغسير الكتاب العزيز،

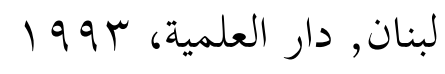

مصطفى صا دق الرافعي، إعجاز القران والبلاغة النبوية، القاهرة :دار المنار، مكتبة فياض بالمنصورة، 199V

جلال الدين السيوطى، المنهر في علوم اللغة وأنواعه، بيروت، دار الكتب، العلمية م) 991

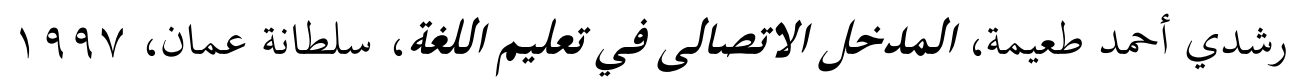

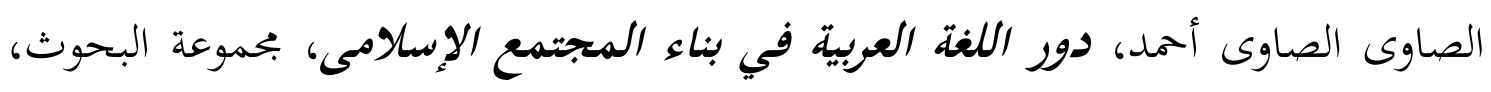

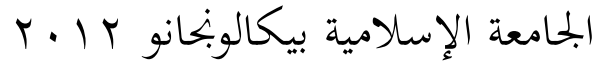

$$
\begin{aligned}
& \text { على عبد الواحد وافف و كمال بشر، الأصوات العربية }
\end{aligned}
$$

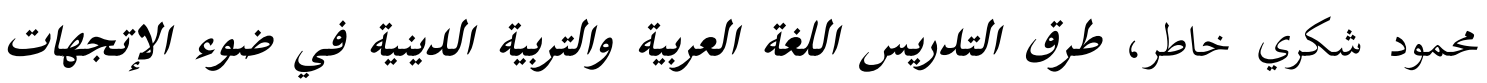

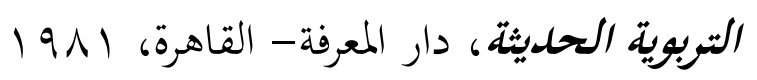

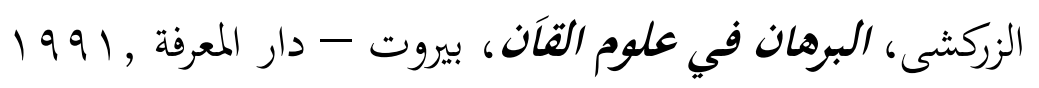

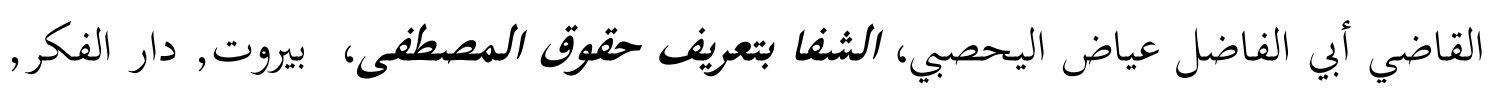

$$
1991
$$

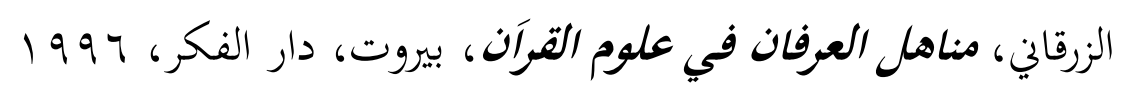

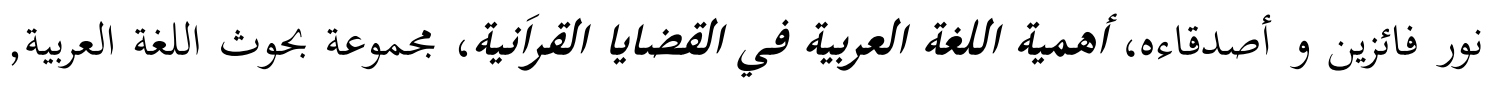
$r .10$ 